\title{
Protection and Promotion of Migrants' Social Rights by the European Committee of Social Rights
}

Protection et promotion des droits sociaux des migrants par le Comité européen des droits sociaux

Protección y promoción de los derechos sociales de los migrantes de la parte del Comité Europeo de Derechos Sociales

\section{Marie-Françoise Valette}

Translator. Alexandra Pomeon

\section{(2) OpenEdition}

\section{Electronic version}

URL: https://journals.openedition.org/remi/10420

DOI: $10.4000 /$ remi. 10420

ISSN: $1777-5418$

This article is a translation of:

Protection et promotion des droits sociaux des migrants par le Comité européen des droits sociaux URL : https://journals.openedition.org/remi/7894 [fr]

Publisher

Université de Poitiers

Printed version

Date of publication: 1 December 2016

ISBN: 979-10-90426-29-0

ISSN: 0765-0752

\section{Electronic reference}

Marie-Françoise Valette, "Protection and Promotion of Migrants' Social Rights by the European Committee of Social Rights", Revue européenne des migrations internationales [Online], vol. 32 - n³ et 4 । 2016, Online since 20 avril 2019, connection on 28 juin 2022. URL: http://journals.openedition.org/ remi/10420 ; DOI: https://doi.org/10.4000/remi.10420

This text was automatically generated on 15 April 2022.

(c) Université de Poitiers 


\title{
Protection and Promotion of Migrants' Social Rights by the European Committee of Social Rights
}

\author{
Protection et promotion des droits sociaux des migrants par le Comité européen \\ des droits sociaux \\ Protección y promoción de los derechos sociales de los migrantes de la parte del \\ Comité Europeo de Derechos Sociales
}

\section{Marie-Françoise Valette}

Translation : Alexandra Pomeon

1 The activities of the European Court of Human Rights (ECHR) are today relayed in the media to such an extent that it is widely known that, despite the absence of rights specifically related to migration in the European Convention on Human Rights, the Court has developed a rich and diverse body of case-law in this area. In contrast, the European Committee of Social Rights (ECSR), responsible for monitoring compliance with State obligations under the Social Charter ${ }^{1}$ remains largely invisible. Yet this Charter was intended as the counterpart to the European Convention on Human Rights, in relation to social rights, within the Council of Europe. It must be acknowledged that the ECSR is not actually a court but an expert body, which was only established almost forty years after the $\mathrm{ECHR}^{2}$, that social rights have long been considered the poor relations of human rights and that the Social Charter does not apply to all foreign nationals. This unequal reputation is particularly exacerbated by the fact that - subject to certain conditions ${ }^{3}$ - any individual claiming to be a victim of a violation of rights under the European Convention on Human Rights can file a complaint to the ECHR. Conversely, again within a Europe composed of 47 Member States, the European Committee of Social Rights can only receive collective complaints from international non-governmental organisations or unions. 
2 Within the European Union, yet another situation can be observed. Indeed, access to the Court of Justice of the European Union (ECJ) is not impossible for individuals. However, in relation to issues concerning migrants' rights, the ECJ mainly issues decisions in response to questions submitted by national judges - preliminary rulings who themselves have received individual complaints related to European Union law.

Until the last decade, these differences could not be interpreted in the light of any competition, in particular in the area of migrants' social rights.

However, the Committee through its creative, sometimes bold interpretations of the Charter, increasingly contributes to promoting the social rights of migrants, refugees and Roma. It could be entitled to increased visibility. The originality of its operation, especially the role accorded to INGOs, but also ongoing cases, in particular a case on the reception and support of unaccompanied foreign minors in France ${ }^{4}$, and a new case concerning Roma children ${ }^{5}$, make this quasi-court of growing interest in the area of migration, in the absence of a wide audience. At the same time, it is becoming increasingly apparent that the European Court is extending its jurisdiction to economic and social rights and the European Union, through the Lisbon Treaty, has given binding force to its Charter of Fundamental Rights, which combines economic and social rights and civil and political rights.

5 Paradoxically, these developments risk rendering the ECSR even less visible (AkandjiKombé, 2014), despite the fact that they should be viewed as reasons for making its activities known outside a small circle of specialists.

\section{The assertion of social rights}

6 Following challenges to their legal character, social rights now appear to be indisputably amenable to the courts (Roman, 2012) and increasingly inseparable from civil and political rights, although the interrelation has proven controversial.

\section{Social rights, the poor relations of human rights}

7 For a long time, the binding nature of economic and social rights was denied, in particular due to confusion between the absence of an obligation to achieve a specific result and the absence of any obligation. The political and costly aspects seemed incompatible with any genuine commitment. Yet, the ECSR and, in the context of the UN, the Committee on Economic, Social and Cultural Rights, highlighted the requirements for progressive fulfilment of rights and the importance of States' positive obligations outside the traditional categories. Thus, in October 2015, the ECSR recalled that in 2003 it had concluded that: "When the achievement of a right in question is exceptionally complex and particularly expensive to resolve, States Parties must attempt to achieve the objectives of the charter within a reasonable time, with measurable progress and making maximum use of available resources" 6 . However, all too often distinctions between first, second and third generation rights or between rights as freedoms and rights as benefits continue to be raised. Yet, today, even neoliberals acknowledge that all rights may carry a "cost" (Lacroix and Pranchère, 2016). 


\section{The indivisibility of human rights}

8 The Universal Declaration of Human Rights did not apply a distinction between civil and political rights and economic, social and cultural rights. Subsequently, at the universal level, the adoption in 1966 of two covenants, each concerning a different set of rights, contributed to entrenching this separation. At the regional level, Member States of the Council of Europe adopted a limited convention from the beginning. There are no social or economic rights in the European Convention on Human Rights.

9 The indivisibility and the interdependence of these various human rights are now acknowledged, by both the European Court and the ECSR.

\section{The evolving interpretation of the personal scope of application of the European Social Charter}

10 Despite the fact that since the end of the Second World War, international protection of human rights has acquired an objective dimension, the personal scope of application of the European Social Charter remains limited. In contrast to other regional or universal conventions, its provisions are not a priori applicable to all persons under the control of a State party.

\section{Migrants included in the definition of the scope of application}

11 Three categories of non-nationals of the State of residence are very explicitly included in both Charters. These are migrant workers, refugees and stateless persons:

12 - A distinction is applied within the category of migrant workers between those who are nationals of another Member State of the Council of Europe which is party to the Charter, and other foreign workers. The Charter includes an article which deals specifically with migrant workers and their families which seems to cover all migrant workers, although it remains somewhat vague. In any case, differences in treatment can be deemed to be compatible with this treaty. In other words, migrant workers do not automatically enjoy all of the rights protected by the Charter.

13 - Refugees are referred to in the Appendix to both versions of the Charter, as are stateless persons.

The ECSR, alarmed by the situation of refugees from the summer of 2015, alongside all the bodies of the Council of Europe ${ }^{7}$, sought to clarify the acceptance which must be accorded to this category of migrants, as well as their rights. It thus adopted a relatively long statement of interpretation on these issues, in order to guide States in the implementation of rights protected under the Charter. It stated in particular that refugees must be protected under the Charter where their situation corresponds to that defined in the 1951 Convention, irrespective of the "administrative recognition of refugee status by a State, which is done by the granting of asylum".

\section{Extension of certain rights to migrants in an irregular situation}

15 The objective vision of international human rights protection does not allow any individual to be excluded from its remit. However, only the Convention on the 
Protection of the Rights of All Migrant Workers and Members of their Families, adopted in the framework of the UN in 1996, explicitly mentions the rights of migrants in an irregular situation, at the cost of the absence of participation of all the northern destination States.

In the name of human dignity, the ECSR has given a very extensive interpretation to the scope of personal application of the Social Charter, specifically including migrants in an irregular situation. The adoption of a teleological interpretation led it to broaden State obligations, at first hesitantly (Daugareilh, 2005), and then more firmly (Nivard, 2014), in relation to several rights deemed to be essential. It was in this way that a step forward, which had been hinted at in 2004, was finally taken in July 2014, through two decisions concerning the Netherlands. In both cases restrictions on access to emergency assistance were challenged. The need to respond to essential needs even led the ECSR to invite the Dutch government to adopt immediate measures, a move which remains entirely exceptional.

These extensions to the scope of application of the Social Charter are all the more remarkable in that, on the one hand, they do not in any way follow from the texts whose implementation the ECSR is supposed to monitor, and on the other, none of the States parties which were asked in 2011 to extend the benefit of social rights to all persons under their jurisdiction have to date accepted to do so (Nivard, 2014).

\section{The monitoring mechanisms of the European Committee on Social Rights}

18 At the outset, the 1961 Charter only provided for one type of monitoring, examination of reports, by a Committee of Experts, under the authority of a body composed of State representatives. However, in 1995, a collective complaints system was introduced in order to give a new impetus to the European Social Charter (Sudre, 1996). In each case, the ECSR's conclusions and decisions have to be endorsed by the Committee of Ministers of the Council of Europe, made up of representatives of the forty-seven Member States. These two mechanisms are inspired by the system existing at the International Labour Organisation (ILO).

\section{Examination of reports}

Each State Party has an obligation to submit an annual document to the Committee in which it presents the conditions for application of the provisions which it has accepted. It can in particular explain the difficulties encountered and the way in which comments made during examination of a previous report have been taken into consideration.

This type of monitoring is common in international law. All the human rights protection conventions adopted within the framework of the United Nations provide for similar mechanisms ${ }^{8}$. The same applies to the International Labour Organisation (ILO), in which such a mechanism has existed since 1926! This organisation is involved in similar areas to the ECSR and is closely linked to its work.

21 Since 2006, with a view to reducing the workload both of States and the ECSR, each provision is only examined every four years. To this end, the rights protected have 
been divided into four themes. One of these groups is composed of obligations related to children, the family and migrants. This is the one which was selected for the 2015 review. In relation to each theme, the ECSR determines the questions. For example, the review concerned language and integration tests and the housing conditions imposed with a view to family reunification, but also opportunities to access housing or measures taken to protect vulnerable populations, such as Roma.

\section{Collective complaints}

The right to submit a complaint is restricted to unions and international nongovernmental organisations with consultative status with the Council of Europe, registered on a specific list and with recognised competence in the area concerned by the complaint ${ }^{9}$. Currently there are seventy-two such organisations. This right can only be exercised against States which have recognised it, namely fifteen States as of the end of July 2016. Complaints which have reached a conclusion have been submitted by quite a diverse range of INGOs and unions. However, the European Roma Rights Centre stands out, with eight complaints which have reached a conclusion. This INGO trains its members on collective complaints and explains to them in particular the value of being familiar with the reports issued by the ECSR in relation to each State, in order to argue complaints effectively ${ }^{10}$. Furthermore, it offers an overview of complaints in which it highlights those which have led to changes in the legislation challenged. It suggests using the media to increase pressure on recalcitrant States.

The value of this type of complaint is that it brings situations faced by groups of persons to the attention of the Committee, rather than individual situations. It enables a civil society organisation to denounce a state practice or legislation which fails to comply with the provisions of the Charter binding the State which is the subject of the complaint. The choice of this mechanism, rather than a court system like that of the ECHR is often lamented and deemed a missed opportunity to give social rights the same chances of effectiveness as those protected under the European Convention on Human Rights (Sudre, 1996). However, it has several advantages. Thus, in contrast to applications to the ECHR, authors of the complaint are not direct victims, rather they are sort of whistle-blowers. They use the "force of law" (Israël, 2009) and enable the establishment of a close link between activist demands and a quasi-court system.

At the conclusion of fairly long proceedings during which the State concerned can respond in detail to the complaint, the ECSR adopts and makes public a decision on the merits. This is formally transmitted to the parties but also to the Committee of Ministers of the Council of Europe which can adopt a recommendation against a State which fails to demonstrate willingness to conform to the ECSR's decision.

These mechanisms are forms of "monitoring" of the obligations arising from the Social Charter. Although neither the report process nor the collective complaints procedure result in enforceable decisions, they nevertheless must be followed-up by the national authorities. 


\section{BIBLIOGRAPHY}

Akandji-Kombé Jean-François (2014) Droit constitutionnel, droit international et droit européen des droits de l'homme : concurrence, confusion, complémentarité ?, Droit social, 4, pp. 301-307.

Boissard Béatrice (2010) La contribution du comité européen des droits sociaux à l'effectivité des droits sociaux, Revue du droit public et de la science politique en France et à l'étranger, 4, pp. 1053-1111.

Daugareilh Isabelle (2005) L'audace retenue du Comité européen des droits sociaux. À propos de la décision FIDH c/ France réclamation n¹4/2003, Revue de droit sanitaire et social, pp. 555-564.

Israël Liora (2009) L'arme du droit, Paris, Les Presses de Sciences Po, 142 p.

Lacroix Justine et Pranchère Jean-Yves (2016) Le procès des droits de l'homme. Généalogie du scepticisme démocratique, Paris, Seuil, $352 \mathrm{p}$.

Marguénaud Jean-Pierre et Mouly Jean (2011) Le Comité européen des droits sociaux, un laboratoire d'idées sociales méconnu, Revue du droit public, 3, pp. 685-716.

Nivard Carole (2014) Précisions sur les droits de la Charte sociale européenne bénéficiant aux étrangers en situation irrégulière, La Revue des droits de l'homme, consulté le 27/01/2016 [en ligne]. URL : https://revdh.revues.org/982

Roman Diane (2012) La justiciabilité des droits sociaux ou les enjeux de l'édification d'un État social, La revue des droits de l'homme, consulté le 29/07/2016 [en ligne]. URL : revdh.revues.org/635

Sudre Frédéric (1996) Le protocole additionnel à la Charte sociale européenne prévoyant un système de réclamations collectives, Revue Générale de Droit International Public, 100 (3),

pp. 715-739.

\section{NOTES}

1. For the sake of precision, we should refer to the European Social Charters. A first version was signed in Turin in 1961 and a version known as the revised version in 1996. Between the two, three additional protocols were signed. Today, there are several States who remain bound only by the 1961 Charter.

2. The European Court of Human Rights was established in 1959. It was only in 1995 that an additional protocol to the Social Charter established a collective complaints procedure to the ECSR.

3. The individual must be under the jurisdiction of a Member State of the Council of Europe, i.e., generally, on its territory and must have exhausted domestic remedies, that is $\mathrm{s} /$ he must have had recourse to the courts of the State concerned.

4. Complaint No. 114/2015 submitted by EUROCEF on 27 February 2015 against France.

5. Complaint No. 119/2015 submitted by FERV on 19 October 2015 against France.

6. Statement of interpretation on The rights of refugees under the European Social Charter, 21, 5 October 2015, [online] visited on 02/08/2016. URL: http://hudoc.esc.coe.int/eng/?i=2015_163_10/ EN

7. Concern which led, in particular, to the appointment of Tomáš Boček in January 2016 as Special Representative on Migration and Refugees of the Council of Europe Secretary General. 
8. In particular the analysis of the report submitted by France by the United Nations Committee on the Rights of the Child, Concluding observations on the fifth periodic report of France, January 2016, [online] visited on 02/08/2016. URL: https://undocs.org/CRC/C/FRA/CO/5

9. Under certain conditions, an entirely national NGO can also submit a collective complaint.

10. Compte-rendu de la formation destinée aux personnes impliquées dans la défense du droit des Roms et voyageurs [Report on training for persons involved in defending the rights of Roma and travellers, in French], 19-20 February 2009, [online] visited on 04/08/2016. URL: http:// romeurope.org/IMG/pdf/

Les_20reclamations_20collectives_20au_20Conseil_20de_20l_Europe.pdf

\section{INDEX}

Keywords: European Court of Human Rights (ECHR), Council of Europe, Court of Justice of the European Union (CJEU), European Union, European Roma Rights Centre, refugees, Roma, United Nations (UN), European Social Charter

Mots-clés: Cour européenne des droits de l'homme (CEDH), Conseil de l'Europe, Cour de justice de l'Union européenne (CJUE), Union européenne (UE), Centre européen des droits des Roms, réfugiés, Roms, Organisation des Nations unies (ONU), Charte sociale européenne

Palabras claves: Tribunal Europeo de Derechos Humanos (TEDH), Consejo de Europa, Tribunal de Justicia de la Unión Europea (TJUE), Unión Europea, Centro Europeo de los Derechos de los Roms, refugiados, Gitanos, Organización de Naciones Unidas (ONU), Carta Social Europea

\section{AUTHORS}

\section{MARIE-FRANÇOISE VALETTE}

Public Law, Lecturer, MIGRINTER, University of Poitiers/CNRS, MSHS, Bât. A5, 5 rue Théodore Lefebvre, TSA 21103, 86073 Poitiers cedex 9; marie.francoise.valette@univ-poitiers.fr 